\title{
Quality and storage stability of tamarind juice
}

\section{Qualidade e estabilidade de suco de tamarindo na estocagem}

\author{
Johnnathan Lima Maia ${ }^{1}$, Nédio Jair Wurlitzer ${ }^{2 *}$ (D), Janice Ribeiro Lima ${ }^{3}$ (D), \\ Maria de Fátima Borges ${ }^{2}$, Monique de Oliveira Maia1 ${ }^{1}$ Bruno Silva Damião1, \\ Luciana de Siqueira Oliveira ${ }^{1}$ \\ ${ }^{1}$ Universidade Federal do Ceará (UFC), Departamento de Engenharia de Alimentos, Fortaleza/CE - Brasil \\ ${ }^{2}$ Embrapa Agroindústria Tropical, Fortaleza/CE - Brasil \\ ${ }^{3}$ Embrapa Agroindústria de Alimentos, Guaratiba/RJ - Brasil
}

*Corresponding Author: Nédio Jair Wurlitzer, Embrapa Agroindústria Tropical, Rua Dra. Sara Mesquita, 2270,

Pici, CEP: 60511-110, Fortaleza/CE - Brasil, e-mail: nedio.jair@embrapa.br

Cite as: Maia, J. L., Wurlitzer, N. J., Lima, J. R., Borges, M. F., Maia, M. O., Damião, B. S., \& Oliveira, L. S. (2021)

Quality and storage stability of tamarind juice. Brazilian Journal of Food Technology, 24, e2020027.

https://doi.org/10.1590/1981-6723.02720

\begin{abstract}
Tamarind is a tropical fruit with relevant importance for family agriculture, and can be used as raw material for a ready-to-drink juice; however, there are few data in the literature associated with the tamarind juice storage stability. This work aimed to evaluate the physicochemical, sensory and microbiological stability of tamarind juice throughout storage at room temperature $\left(\sim 28^{\circ} \mathrm{C}\right)$ for 180 days. Two juice formulations were produced, a control $(\mathrm{pH} 2.5)$, and the formulation with acidity reduction $(\mathrm{pH} 3.5)$. Physicochemical $(\mathrm{pH}$, acidity, and soluble solids), sensory and microbiological analyses were performed for both juices along storage. The results showed that both juices were stable regarding all physicochemical parameters analyzed. Furthermore, both juices kept sensory scores in the acceptance zone, despite little changes in attributes (tamarind, sour, and sweet taste) for the partially neutralized juice $(\mathrm{pH}$ 3.5). Microbiological results were also stable for the period analyzed, which indicated efficient good manufacturing process alongside efficient heat treatment. Therefore, both juices can be stored at room temperature without presenting quality loss.
\end{abstract}

Keywords: Tamarindus indica L.; Shelf-life; Sensory acceptance; Sensory attributes; Microbiological stability; Color stability.

\section{Resumo}

O tamarindo é uma fruta tropical de grande importância para a agricultura familiar e pode ser utilizada como matéria-prima para suco pronto para beber. No entanto, existem poucos dados na literatura sobre sua estabilidade. Este trabalho teve como objetivo avaliar a estabilidade do suco de tamarindo durante o armazenamento em temperatura ambiente $\left(\sim 28^{\circ} \mathrm{C}\right)$ por 180 dias. Duas formulações foram produzidas, sendo um tratamento controle $(\mathrm{pH} 2,5)$ e um suco com acidez parcialmente reduzida $(\mathrm{pH} 3,5)$. Análises físico-químicas $(\mathrm{pH}$, acidez e sólidos solúveis), de cor, sensoriais e microbiológicas foram realizadas para ambos os sucos, durante o armazenamento. Os resultados mostraram que os sucos foram estáveis em relação a todos os parâmetros físico-químicos analisados. Além disso, mantiveram escores de aceitação global estáveis, apesar de pequenas mudanças nos atributos - gosto 
de tamarindo, ácido e doce - para o suco parcialmente neutralizado ( $\mathrm{pH} \mathrm{3,5).} \mathrm{Os} \mathrm{sucos} \mathrm{apresentaram} \mathrm{também}$ estabilidade microbiológica no período analisado, o que indicou um processo de fabricação e tratamento térmico eficientes. Portanto, ambos os sucos podem ser armazenados à temperatura ambiente, sem apresentar perda de qualidade.

Palavras-chave: Tamarindus indica L.; Vida de prateleira; Aceitação sensorial; Atributos sensoriais; Estabilidade microbiológica; Estabilidade de cor.

\section{Introduction}

Tamarind (Tamarindus indica L.) is a tropical fruit widely found in the Northeast region of Brazil in spontaneous plantations and has recently been the subject of planned plantations for scale production, considering the adaptation to the semi-arid region. In addition, tamarind has relevant social importance for family agriculture, making it necessary to develop products that use it as a raw material to increase its commercial interest. Tamarind is also considered a non-conventional food plant (Plantas Alimentícias Não Convencionais (PANC)), and used with beneficial health effects, with a low glycemic index (Passos, 2017). The development of a ready-to-drink tamarind juice could become an alternative to the market.

The Brazilian tamarind has a strong sour taste, and it is still little explored for elaboration of derivatives, however, its nutritional properties are reported in several studies, highlighting the antioxidant property of these compounds (Recuenco et al., 2016), even as the low glycemic index and benefits for diabetics (Passos, 2017). Nevertheless, its strong sour taste is a barrier to sensory acceptance, which could lead to low consumption of tamarind products.

In order to increase the sensorial acceptance of tamarind juice, Embrapa Agroindústria Tropical developed a process to reduce its acidity, in which a $\mathrm{pH}$ value was established to improve overall acceptance of the juice. In this process, the formulation was standardized to a ratio of $10 \mathrm{~g}$ of solid content in $100 \mathrm{~g}$ of juice, which alongside $\mathrm{pH}$ adjustment up to 3.5 , increased sensory acceptability, thus allowing the addition of higher pulp content to the ready-to-drink juice.

The stability of fruit juices is related to chemical reactions and microbiological factors that cause undesirable changes compromising product quality and safety, such as nutritional and sensorial loss (Freitas et al., 2006). The study of stability can be performed by evaluating quality parameters such as sensory acceptance, physicochemical parameters, nutritional value and microbial load for a period up to the limit of acceptance. Tavares et al. (2020) evaluated jambolan powder juice and observed parameters oscillation during storage, without major losses after 150 days in cold or room temperature. However, there are few data in the literature associated with the tamarind juice storage stability.

Thus, this work aimed to evaluate the physicochemical, sensory and microbiological stability of tamarind juices throughout storage at room temperature $\left(\sim 28^{\circ} \mathrm{C}\right)$ for 180 days.

\section{Material and methods}

\subsection{Material}

Tamarind fruits were completely ripped and peeled in plastic packaging from the commercial production from Russas, in Ceará State, and stored at $-18^{\circ} \mathrm{C}$ until use for pulp and juice production.

\subsection{Formulations}

Two tamarind juice formulations were prepared: control " $\mathrm{C}$ " $(\mathrm{pH} 2.5)$, and the formulation with juice with acidity reduction " $\mathrm{N}$ " (pH 3.5). The tamarind pulp and water were weighed and mixed, and adjusted to a ratio 
of $10 \mathrm{~g}$ of total solids per $100 \mathrm{~g}$ of total volume of juice. The sweetener stevia powder was added, comprising $0.1 \%$ over the total volume, and manual homogenization of the juice was performed. The juice was then split into two equal parts, where one was defined as "control" without adjustment, and other had $\mathrm{pH}$ adjusted to 3.5 , using $15 \%$ of potassium hydroxide $(\mathrm{KOH})$ solution. The formulations were planned to meet the technical regulation of identity and quality standards established in IN 37/2018 (Brasil, 2018).

The formulations prepared were pasteurized in a tubular exchanger (Armfield FT74, Ringwood, England) at $85{ }^{\circ} \mathrm{C}$ using flow and holding tube for 30 seconds, and then hot filled in $210 \mathrm{~mL}$ glass bottles, previously sanitized with active chlorine (100 $\left.\mathrm{m} \mathrm{L}^{-1}\right)$, and closed with a plastic screw cap. The bottles were put upside down for cap pasteurization, for 3 minutes, cooled in a water bath, labeled and stored at room temperature.

\subsection{Stability of tamarind juice}

The stability test of the two juices was performed at room temperature $\left(\sim 28{ }^{\circ} \mathrm{C} \pm 2{ }^{\circ} \mathrm{C}\right)$, without illumination control, simulating the condition of a supermarket shelf for 180 days. The samples were collected 1 day after processing, and also during storage (around 20, 50, 80, 130, and 180 days). Physicochemical and microbiological analyses were performed in order to correspond to the six storage times, whereas color and sensorial analyses were performed in order to correspond to five storage times.

\subsubsection{Physicochemical stability}

The physicochemical analyses ( $\mathrm{pH}, \mathrm{SS}, \mathrm{TA}$, and moisture), used in each collection point, were performed according to Instituto Adolfo Lutz (2008) for Soluble Solids (SS), Total Acidity (TA) and moisture. In addition, the $\mathrm{pH}$ analysis was performed according to Association of Official Analytical Chemists (2016).

For the total color difference $(\Delta \mathrm{E}$, Equation 1$)$, the coordinates $\mathrm{L}^{*}, \mathrm{a}^{*}, \mathrm{~b}^{*}$ were determined using a colorimeter (Chroma Meter CR-400, Konica Minolta Sensing Inc., Osaka, Japan), and the measurement obtained in the storage time under evaluation was compared with values obtained at time zero (after processing).

$\Delta E=\sqrt{(\Delta L)^{2}+(\Delta a)^{2}+(\Delta b)^{2}}$

The results obtained for the total color difference were compared to the ranges defined by Mokrzycki \& Tatol (2011), which indicate the limits of ability to observe the color difference by tasters.

\subsubsection{Sensory stability}

The sensorial analysis, at each collection point, was applied with 52 untrained testers, of both sexes and wide age group, non-smokers and used to drink fruit juices regularly. Throughout the storage assessment, testers were recruited at each session, and some of them participated in more than one session - storage assessment evaluation. It was applied an affective test for overall acceptance using a structured 9-point hedonic scale, ranging from "Dislike it extremely (1)" to "Like it extremely" (9), and an average result above 6 (on the 9-point scale) was considered acceptable. In addition, it was performed a Scoring method to evaluate the intensity of the following attributes: tamarind taste; sour taste; and sweet taste; using a 7-point hedonic scale (Meilgaard et al., 2006). The protocols of the sensorial tests were previously approved by the Research Ethics Committee of the Ceará State University (No. 147.279), according to Resolution 466/2012 (Brasil, 2012).

\subsubsection{Microbiological stability}

The microbiological quality of the tamarind juice samples was evaluated by the total count of aerobic mesophilic microorganisms, filamentous fungi and yeasts, fecal coliforms, Escherichia coli and Salmonella spp., as described in 
the Food and Drug Administration (FDA) regarding Bacteriological Analytical Manual (BAM) (Andrews et al., 2016; Feng et al., 2017). The results were expressed in CFU/mL for aerobic mesophilic microorganisms, fecal coliforms, E. coli and filamentous fungi and yeasts. For Salmonella spp., the result was expressed in absence $/ 25 \mathrm{~mL}$ of juice. Analyzes were performed in three replicates, thus being evaluated three packaged samples at each time.

\subsection{Statistical analyses}

The results for physicochemical and sensory stability were analyzed using a linear regression performed in a spreadsheet (Excel - Microsoft software), and the regression $p$-values of $p<0.05$ were considered significant, and they were then presented in the graphs only when they were considered significant. The overall acceptability scores between treatment $\mathrm{C}$ and $\mathrm{N}$ were evaluated by Analysis of Variance (ANOVA), with significance of 0.05 . Regarding the results for microbiological analyzes, compliance with the current legislation was observed (Brasil, 2019a, 2019b).

Analyzes were carried out in triplicate at each storage time, using three bottles for physicochemical and microbiological analyses, and six bottles for sensory analysis.

\section{Results and discussion}

\subsection{Stability of tamarind juice}

\subsubsection{Physicochemical and color stability}

The results for physicochemical stability of the two tamarind juice formulations under storage at room temperature are shown in Figure 1. Both $\mathrm{pH}$ and acidity values remained close to the ones obtained after juice processing indicating stability during storage at room temperature. In the statistical evaluation, the regression analysis was significant only for the $\mathrm{pH}$ results of tamarind juice with partially neutralized acidity, so only this equation was presented in the graph. However, the slope of this equation was small in magnitude, confirming stability to storage.
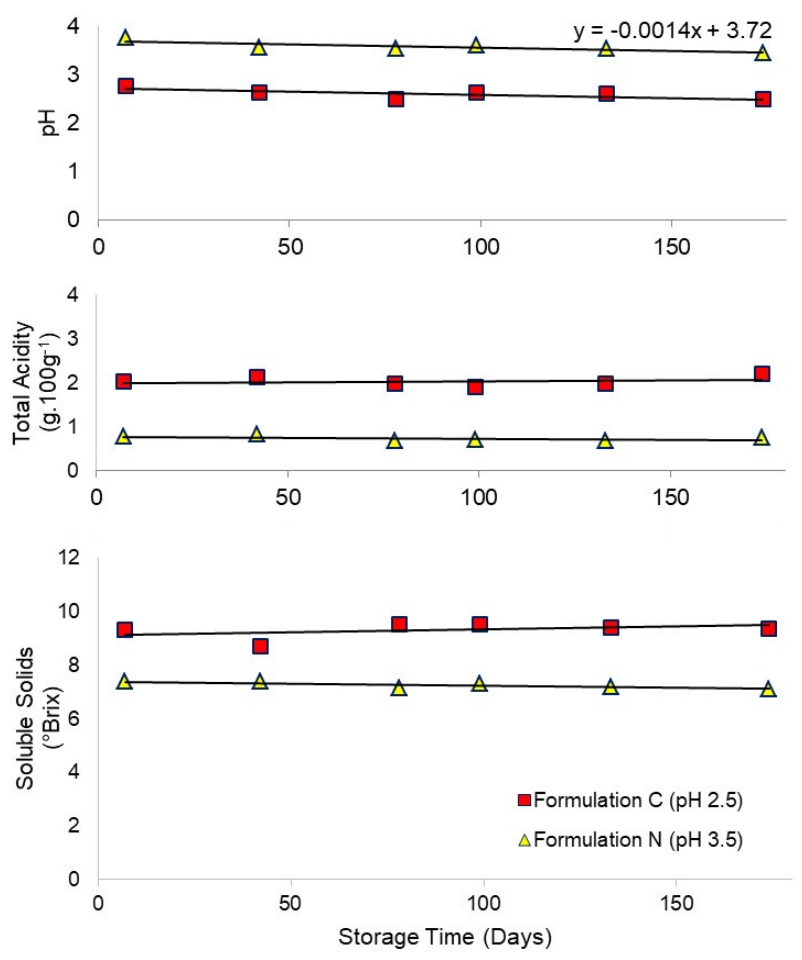

Figure 1. Stability of physicochemical parameters of tamarind juice throughout storage. 
The high acidity of the juices alongside the hot-fill pasteurization process, considered a process standard for acid juices, as well as the acidity stability could indicate that the heat treatment was efficient and then sealed in airtight packaging, this statement could be confirmed by microbiological analyzes. According to Chim et al. (2013), acidity was an important parameter of product quality, where acidity or $\mathrm{pH}$ changes indicated reactions involved in the decomposition, such as hydrolysis, oxidation and fermentation, generating compounds that increase the acidity of food. Thus, the non-change in acidity and $\mathrm{pH}$ together with the results of microbiological analyzes indicate storage stability.

The evaluation of soluble solids (SS) also demonstrated stability during storage. Regarding acid juices with $\mathrm{pH}$ lower than 4.3, Karaman et al. (2020) observed small pH variations (3.34 to 3.68) and Brix (11.99 to 12.23) during the storage of apple juice for 41 days. Babbar et al. (2015) also evidenced the stability of soluble solids in storage of litchi juice for 180 days, at room temperature, similar to tamarind juice, indicating the stability of the SS response in relation to storage time.

Table 1 shows the values of the total color difference $(\Delta \mathrm{E})$, comparing the values obtained in each time, with those obtained after the processing. Considering the ranges indicated by Mokrzycki \& Tatol (2011), it could be observed that the tamarind juices had values of $\Delta \mathrm{E}$ lower than 3.5, indicating that untrained tasters could observe the color difference. However, for being color differences clearly observed, $\Delta \mathrm{E}$ should be greater than 3.5. These results are confirmed with the photos of the juices at each storage time, presented in Figure 2, and when confronted with the sensorial response, where the tasters did not indicate changes in color, thus characterizing the color stability against storage in room temperature. Tavares et al. (2020) observed that the color of jambolan juice, in storage of up to 150 days at 25 and $35{ }^{\circ} \mathrm{C}$, also showed small variations, and the product became opaquer, without losing its purplish-red color. According to Gadelha et al. (2019), the tamarind juice presented mainly anthocyanins as pigments, followed by chlorophylls and carotenoids ( $0.14 \mathrm{mg} 100 \mathrm{~g}^{-1}, 0.08 \mathrm{mg} 100 \mathrm{~g}^{-1}$ and $\left.1.64 \mu \mathrm{g} 100 \mathrm{~g}^{-1}\right)$. Song et al. (2018) when assessing the stability of blueberry juice, indicated that anthocyanins were degraded by exposure to light and to high temperatures during storage, and even during prolonged storage under refrigeration. In this way, the color change observed in the tamarind juice storage can be related to the anthocyanins oxidation. As the juices were pasteurized, we consider that the enzymes were inactivated. Therefore, we did not relate color degradation during storage to enzymatic activity.

Table 1. Total color difference of tamarind juice of each time comparing with the first day of processing.

\begin{tabular}{ccccccc}
\hline & \multicolumn{6}{c}{ Total color difference $(\Delta \mathrm{E})$} \\
\cline { 2 - 7 } Treatment/storage (days) & $\mathbf{1}$ & $\mathbf{2 0}$ & $\mathbf{5 0}$ & $\mathbf{1 3 0}$ & $\mathbf{1 8 0}$ \\
\hline $\mathbf{C}(\mathbf{p H ~ 2 . 5 )}$ & 0 & 0.5 & 2.8 & 2.1 & 2.7 \\
\hline $\mathbf{N}(\mathbf{p H ~ 3 . 5 )}$ & 0 & 2.6 & 0.4 & 1.1 & 1.6 \\
\hline
\end{tabular}

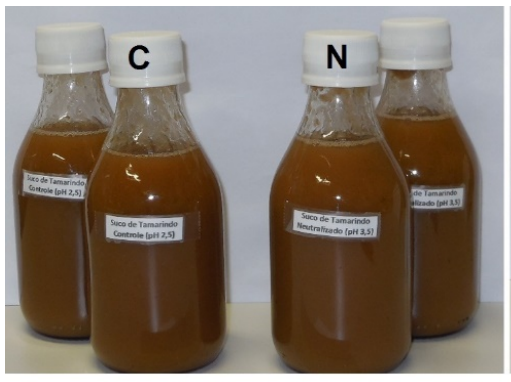

Short after processing

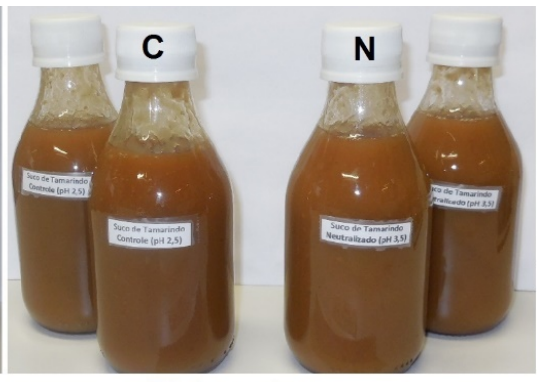

91 days storage

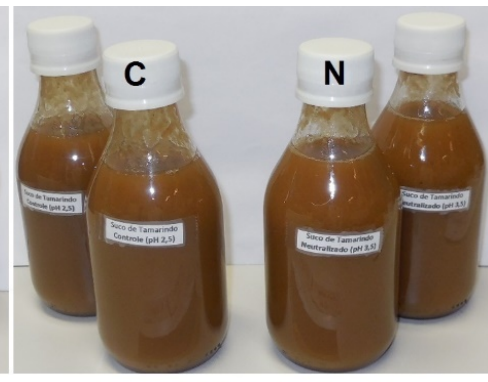

166 days storage

Figure 2. Photos of tamarind juice in three different storage times. 


\subsubsection{Sensory stability}

The results for sensory stability regarding overall acceptance are shown in Figure 3.

The average result of global acceptance by the tasters at each time showed stability during the storage time at room temperature for the evaluated period of 180 days. Treatment "N", tamarind juice with partially reduced acidity ( $\mathrm{pH} 3.5)$, had a higher acceptability score when compared to the control treatment ( $\mathrm{pH} 2.5)$, with scores of 6.7 (acceptance range) and 5.5 (from indifferent to slightly liked), respectively ( $p<0.05$ ). Similar results were obtained by Freitas et al. (2006), for pasteurized and hot-filled acerola juice, maintaining global acceptance for up to 350 days. When analyzing the intensity of the brown color of the juices (Figure 4), both formulations shown stability, with scores corresponding to "dark" intensity, considering the sensory evaluation scale ( $1=$ light, 7 = dark) presented to the panelists, however, slightly higher for treatment A.

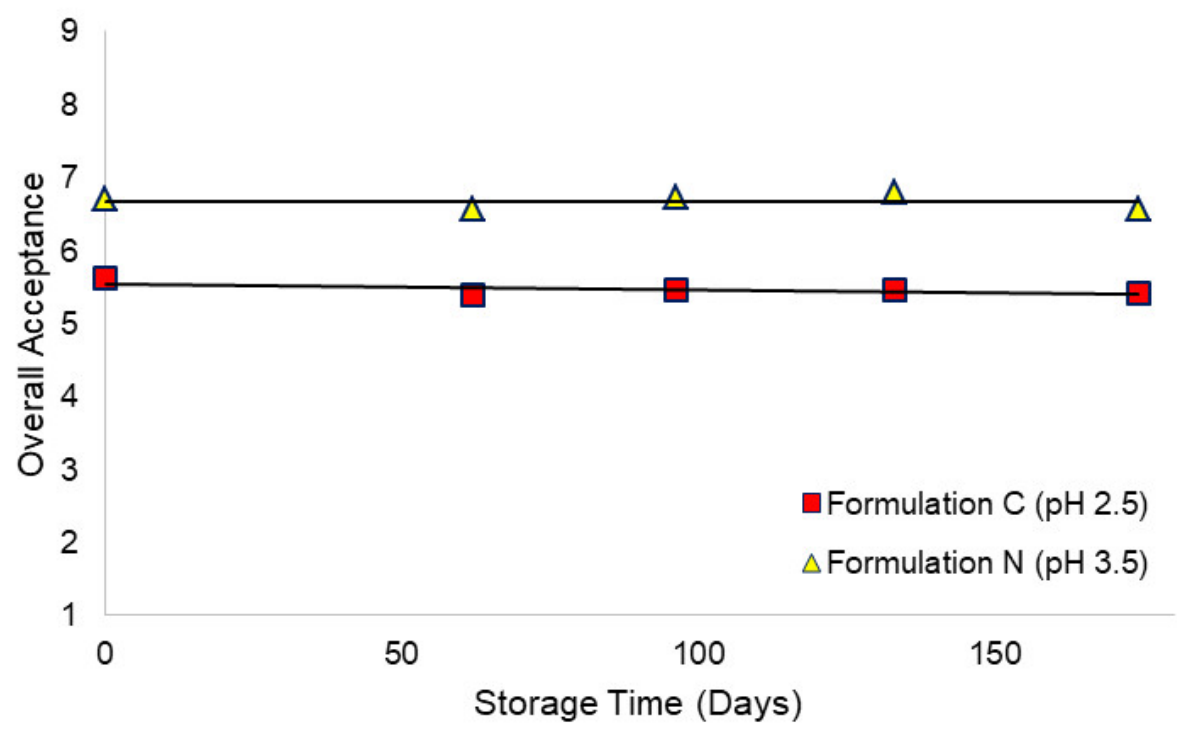

Figure 3. Overall acceptance of tamarind juice throughout storage.

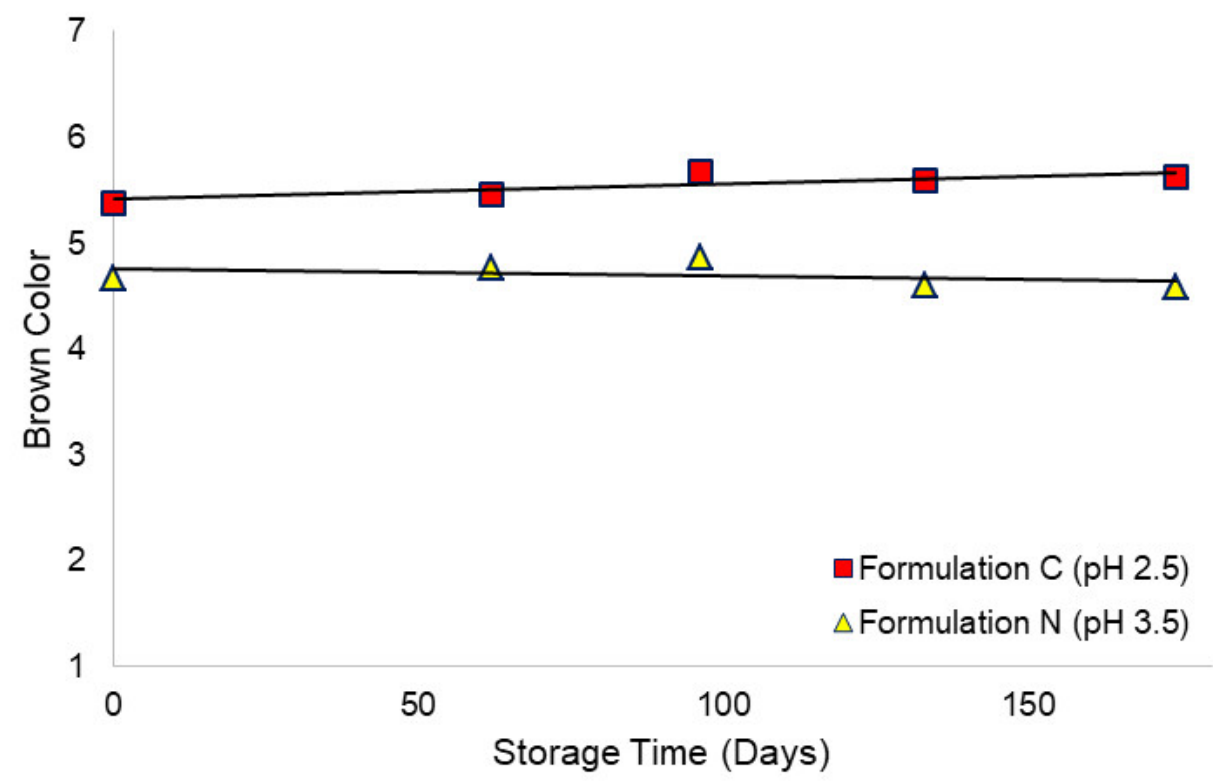

Figure 4. Stability of "brown color" of tamarind juice throughout storage. 
Regarding the "tamarind flavor" attribute, both treatments presented a mean result for "strong" tamarind flavor, but a slight tendency of decreasing of intensity for treatment $\mathrm{N}(\mathrm{pH} 3.5)$ with storage time can be observed. This may have been caused by the loss of intensity of the characteristic sour taste of the fruit and an increase in the perception of sweet taste as indicated in Figure 5, although these attributes may have been the result of the adaptation of the tasters to the juices. In addition, the reduction in the sour taste can be related to tartaric acid crystallization during storage, leading to loss of sour taste perception. However, these slight changes did not reflect the overall acceptance of juice by the tasters, reinforcing their stability over the period analyzed.
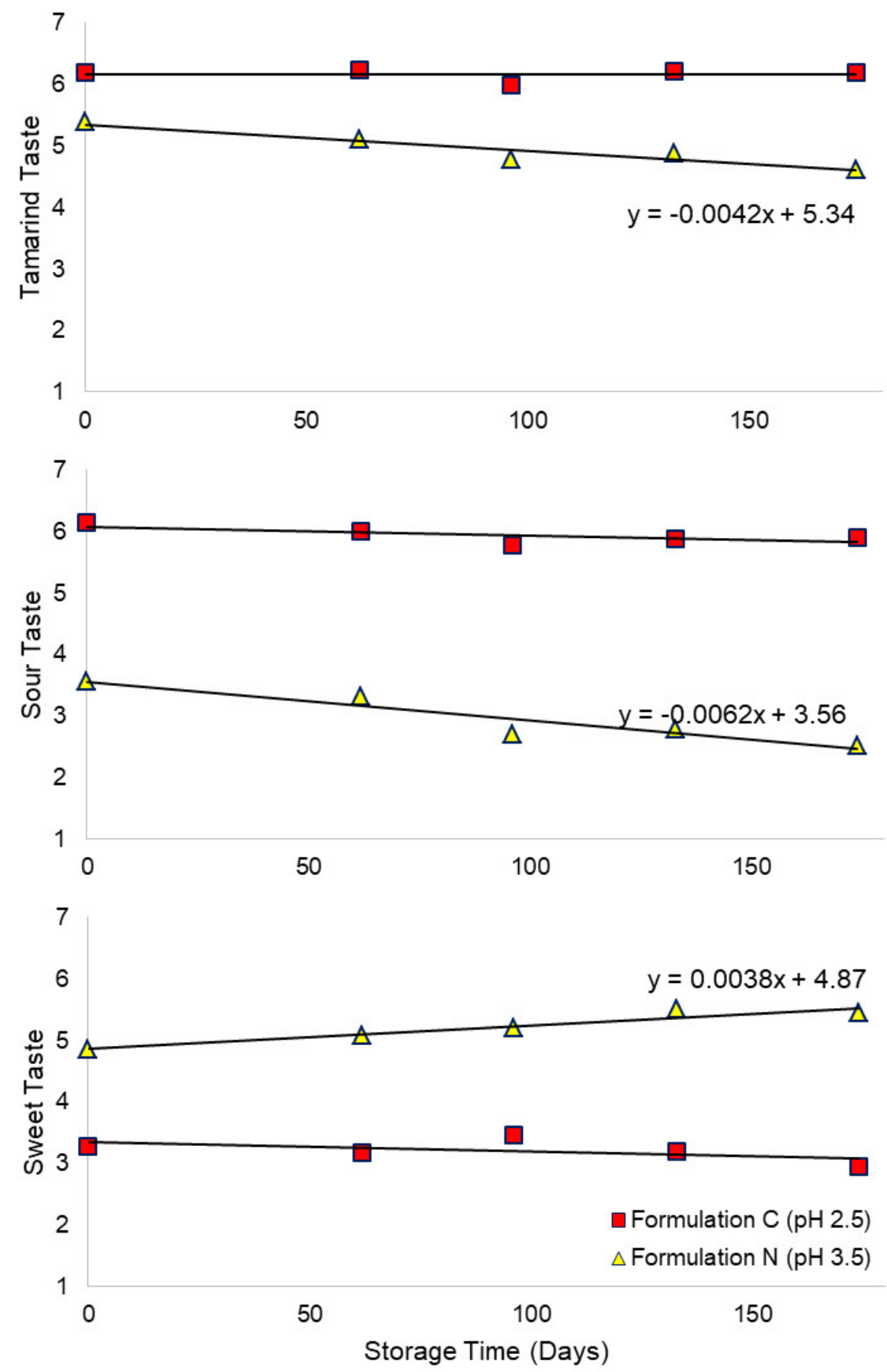

Figure 5. Stability of "tamarind taste", "sour taste", and "sweet taste" parameters throughout storage. 


\subsubsection{Microbiological stability}

Regarding microbiological analyses, it was possible to observe that throughout the storage period, the presence of fecal coliforms, E. coli and Salmonella spp. were not found in both juices during the 180-day period as shown in Table 2. These results indicated that both juices presented hygienic conditions and met the microbiological standards established by legislation (Brasil, 2019a).

Table 2. Microbiological analyses of tamarind juice throughout storage.

\begin{tabular}{|c|c|c|c|c|c|}
\hline Storage (Days) & Samples & $\begin{array}{c}\text { Mesophilic aerobic } \\
(\mathrm{CFU} / \mathrm{mL})\end{array}$ & $\begin{array}{c}\text { Fecal } \\
\text { coliformes and } \\
\text { E. coli } \\
(\mathrm{MPN} / \mathrm{mL})\end{array}$ & $\begin{array}{c}\text { Filamentous fungi } \\
\text { and yeast } \\
(\mathrm{CFU} / \mathrm{mL})\end{array}$ & $\begin{array}{l}\text { Salmonella spp. } \\
\text { (Absence/25 mL) }\end{array}$ \\
\hline \multirow{2}{*}{1} & $\mathrm{C}$ & $<1 \times 10^{1 *}$ & $<3^{*}$ & $<1,0 \times 10^{2 *}$ & Absence \\
\hline & $\mathrm{N}$ & $<1 \times 10^{1 *}$ & $<3 *$ & $<1,0 \times 10^{2 *}$ & Absence \\
\hline \multirow{2}{*}{20} & $\mathrm{C}$ & $<1 \times 10^{1 *}$ & $<3 *$ & $<1,0 \times 10^{2 *}$ & Absence \\
\hline & $\mathrm{N}$ & $<1 \times 10^{1 *}$ & $<3^{*}$ & $<1,0 \times 10^{2 *}$ & Absence \\
\hline \multirow{2}{*}{50} & $\mathrm{C}$ & $<1 \times 10^{1 *}$ & $<3^{*}$ & $<1,0 \times 10^{2 *}$ & Absence \\
\hline & $\mathrm{N}$ & $<1 \times 10^{1 *}$ & $<3^{*}$ & $<1,0 \times 10^{2 *}$ & Absence \\
\hline \multirow{2}{*}{80} & $\mathrm{C}$ & $<1 \times 10^{1 *}$ & $<3 *$ & $<1,0 \times 10^{2 *}$ & Absence \\
\hline & $\mathrm{N}$ & $<1 \times 10^{1 *}$ & $<3^{*}$ & $<1,0 \times 10^{2 *}$ & Absence \\
\hline \multirow{2}{*}{130} & $\mathrm{C}$ & $<1 \times 10^{1 *}$ & $<3^{*}$ & $<1,0 \times 10^{2 *}$ & Absence \\
\hline & $\mathrm{N}$ & $<1 \times 10^{1 *}$ & $<3^{*}$ & $<1,0 \times 10^{2 *}$ & Absence \\
\hline \multirow{2}{*}{180} & $\mathrm{C}$ & $<1 \times 10^{1 *}$ & $<3^{*}$ & $<1,0 \times 10^{2 *}$ & Absence \\
\hline & $\mathrm{N}$ & $<1 \times 10^{1 *}$ & $<3 *$ & $<1,0 \times 10^{2 *}$ & Absence \\
\hline
\end{tabular}

*Detection limit.

The count of aerobic mesophilic bacteria in pasteurized juices was less than $10 \mathrm{CFU} / \mathrm{mL}$ during 180 days at room temperature, regardless of treatment. These results were in accordance with the recommendations of FAO/WHO and APHA's Standard Methods for the Examination of Dairy Products (Lewis et al., 2004).

Considering the microbiological stability results, both juices met the requirements of Brazilian legislation, and could be considered microbiologically safe and had a shelf-life for at least 180 days.

The count of filamentous fungi and yeast was less than $100 \mathrm{CFU} / \mathrm{mL}$ during the storage period. Brazilian legislation establishes a tolerance of $10^{4} \mathrm{CFU} / \mathrm{g}$ in foods such as fruit juices and nectars pasteurized, and results could indicate microbiological stability of the product during storage. These results indicated that the juices were processed under appropriate hygiene and sanitation conditions.

\section{Conclusion}

The results showed that tamarind juice with partial acidity neutralization had better acceptability. In addition, both juice formulations presented stability during 180 days storage. With the increase in storage time, there was a slight reduction in the acid taste and the consequent increase in sweet taste, however, the sensory quality was not affected. Therefore, both juices can be stored at room temperature without quality loss.

\section{Acknowledgements}

Federal University of Ceará - (Universidade Federal do Ceará (UFC)), Embrapa Agroindústria Tropical.

This study was financed in part by the Coordenação de Aperfeiçoamento de Pessoal de Nivel Superior Brasil (CAPES) - Finance Code 001. 


\section{References}

Andrews, W. H., Jacobson, A., \& Hammack, T. S. (2016). Salmonella. In U.S. Food and Drug Administration - FDA (Ed.), Bacteriological analytical manual online (8th ed., Chap. 5). Rockville: FDA.

Association of Official Analytical Chemists - AOAC. (2016). Official methods of analysis of the Association of Official Analytical Chemists (20th ed.). Gaithersburg: AOAC International.

Babbar, N., Aggarwal, P., \& Oberoi, H. S. (2015). Effect of addition of hydrocolloids on the colloidal stability of Litchi (Litchi chinensis Sonn.) juice. Journal of Food Processing and Preservation, 39(2), 183-189. http://dx.doi.org/10.1111/jfpp.12220

Brasil. Conselho Nacional de Saúde. (2012). Diretrizes e normas regulamentadoras de pesquisas envolvendo seres humanos (Resolução n 466, de 12 de dezembro de 2012). Diário Oficial [da] República Federativa do Brasil, Brasília. Retrieved in 2018, October 8, from https://conselho.saude.gov.br/resolucoes/2012/ Reso466.pdf

Brasil. Ministério da Agricultura, Pecuária e Abastecimento. (2018). Regulamento técnico geral para fixação dos padrões de identidade e qualidade para suco de fruta e polpa de fruta (Instrução normativa n 37, de 1 de outubro de 2018). Diário Oficial [da] República Federativa do Brasil, Brasília, edição 194, seção 1, p. 28.

Brasil. Ministério da Saúde. Agência Nacional de Vigilância Sanitária - ANVISA. (2019a, dezembro 26). Estabelece as listas de padrões microbiológicos para alimentos (Instrução normativa $n^{\circ} 60$, de 23 de dezembro de 2019). Diário Oficial [da] República Federativa do Brasil, Brasília, edição 249. Retrieved in 2020, August 24, from https://www.in.gov.br/en/web/dou/-linstrucaonormativa-n-60-de-23-de-dezembro-de-2019-235332356

Brasil. Ministério da Saúde. Agência Nacional de Vigilância Sanitária - ANVISA. (2019b, dezembro 23). Dispõe sobre os padrões microbiológicos e sua aplicação (Resolução - RDC n 331, de 23 de dezembro de 2019). Diário Oficial [da] República Federativa do Brasil, Brasília, edição 249, seção 1, p. 96. Retrieved in 2020, August 24, from https://www.in.gov.br/web/dou//resolucao-rdc-n-331-de-23-de-dezembro-de-2019-235332272

Chim, J. F., Zambiazi, R. C., \& Rodrigues, R. S. (2013). Estabilidade da vitamina C em néctar de acerola sob diferentes condições de armazenamento. Revista Brasileira de Produtos Agroindustriais, 15(4), 321-327. http://dx.doi.org/10.15871/1517-8595/rbpa.v15n4p321-327

Feng, P., Weagant, S. D., Grant, M. A., \& Burkhardt, W. (2017). Enumeration of Escherichia coli and the coliform bacteria. In U.S. Food and Drug Administration - FDA (Ed.), Bacteriological analytical manual online (8th ed., Chap. 4). Rockville: FDA.

Freitas, A. S., Maia, G. A., Costa, J. M. C., Figueiredo, R. W., Rodrigues, M. C. P., \& Sousa, P. H. M. (2006). Estabilidade do suco tropical de acerola (Malpighia emarginata D.C.) adoçado e envasado pelos processos hot-fill e asséptico. Food Science and Technology, 26(3), 544-549. http://dx.doi.org/10.1590/S0101-20612006000300010

Gadelha, M. R. A., Gomes, J. S., Silva, A. K., Alves, M. J. S., \& Santos, A. F. (2019). Blends with tropical fruits based on tamarindo. Revista Verde de Agroecologia e Desenvolvimento Sustentável, 14(3), 412. http://dx.doi.org/10.18378/rvads.v14i3.6215

Instituto Adolfo Lutz - IAL. (2008). Normas analíticas do Instituto Adolfo Lutz: Métodos físico-químicos para análise de alimentos (1. ed. digital, 1020 p.). São Paulo.

Karaman, K., Sagdic, O., \& Yilmaz, M. T. (2020). Potential of natamycin to control growth of Zygosaccharomyces spp. in apple juice during storage. International Journal of Food Microbiology, 332, 108771. PMid:32650062. http://dx.doi.org/10.1016/j.ijfoodmicro.2020.108771

Lewis, D., Spomer, D., Smith, M., \& Clark, W. (2004). Milk and milk products. In H. M. Wehr \& J. F. Frank (Eds.), Standard methods for the microbiological examination of dairy products (17th ed., Chap. 16, pp. 537-550). Washington: American Public Health Association. http://dx.doi.org/10.2105/9780875530024ch16.

Meilgaard, M. C., Carr, B. T., \& Carr, B. T. (2006). Sensory evaluation techniques (464 p.). New York: CRC Press. http://dx.doi.org/10.1201/b16452.

Mokrzycki, W., \& Tatol, M. (2011). Color difference Delta E: A survey. Machine Graphics and Vision, 20(4), 383-411.

Passos, T. U. (2017). Efeito da farinha de tamarindo no controle metabólico de pacientes diabéticos: Ensaio clínico randomizado duplo cego controlado por placebo (Tese de doutorado). Universidade Estadual do Ceará, Fortaleza.

Recuenco, M. C., Lacsamana, M. S., Hurtada, W. A., \& Sabularse, V. C. (2016). Total phenolic and total flavonoid contents of selected fruits in the Philippines. Philippine Journal of Science, 145(3), 275-281.

Song, H. N., Ji, S. A., Park, H. R., Kim, H. H., \& Hogstrand, C. (2018). Impact of various factors on color stability of fresh blueberry juice during storage. Preventive Nutrition and Food Science, 23(1), 46-51. PMid:29662847. http://dx.doi.org/10.3746/pnf.2018.23.1.46

Tavares, I. M. C., Sumere, B. R., Gómez-Alonso, S., Gomes, E., Hermosín-Gutiérrez, I., Da-Silva, R., \& Lago-Vanzela, E. S. (2020). Storage stability of the phenolic compounds, color and antioxidant activity of jambolan juice powder obtained by foam mat drying. Food Research International, 128, 108750. PMid:31955732. http://dx.doi.org/10.1016/j.foodres.2019.108750

Funding: Coordenação de Aperfeiçoamento de Pessoal de Nível Superior - Brasil (CAPES)/Finance Code 001; Empresa Brasileira de Pesquisa Agropecuária - SEG 03141300400. 